http://dx.doi.org/10.12775/szhf.2013.053

\title{
Czy kultura literacka zastąpiła kulturę filozoficzną? O poglądach Richarda Rorty’ego
}

Nie jest tajemnicą, że Richard Rorty bardzo sceptycznie podchodził do idei mówiącej, iż filozofia ma we współczesnych społeczeństwach zachodnich do odegrania jakąśs szczególną rolę w sferze publicznej ${ }^{1}$. Należy przy tym pamiętać, że amerykański myśliciel nie deprecjonował całkowicie filozofii - uważał jedynie, że gdy idzie o debaty nad polityczno-społecznymi problemami, z którymi obecnie zmagają się zachodnie (i nie tylko) demokracje, filozofowie nie mają niczego szczególnego do zaoferowania. W Pierwszeństwie demokracji wobec filozofii przekonywał, że nie da się za pomocą filozofii uzasadnić, iż demokracja jest lepiej dopasowana do natury człowieka niż inne systemy polityczne ${ }^{2}$. W innych tekstach dodawał, że nawet w debatach nad konkretnymi problemami, z jakimi zmagają się współczesne liberalne społeczeństwa

\footnotetext{
${ }^{1}$ Szerzej poglądy Rorty'ego na ten temat omawiam w tekście Rola filozofii we współczesnych demokracjach zachodnich. Analiza tez Richarda Rorty'ego (w przygotowaniu). W niniejszym artykule podaję tylko zarys stanowiska amerykańskiego filozofa, który jest niezbędny, aby zrozumieć moją polemikę z nim. Jeśli chodzi o próbę bardziej całościowego spojrzenia na filozofię Rorty’ego, zob. T. Szubka, Neopragmatyzm, Torun 2012 oraz A. Szahaj, Ironia i miłość. Neopragmatyzm Richarda Rorty'ego w kontekście sporu o postmodernizm, Wrocław 2002.

${ }^{2}$ R. Rorty, Pierwszeństwo demokracji wobec filozofii, [w:] tegoż, Obiektywność, relatywizm i prawda, tłum. J. Margański, Warszawa 1999.
} 
demokratyczne (takimi jak choćby prawa osób homoseksualnych), filozofia nie jest w stanie zbyt wiele zaoferować w celu ich rozwiązania ${ }^{3}$. Równocześnie amerykański myśliciel przyznawał filozofii istotne miejsce w sferze prywatnej. Twierdził, że zdarzają się ludzie, którzy odczuwają potrzebę czytania tekstów filozoficznych i czerpią z tego osobistą satysfakcję. Nie negował on też faktu, że obcowanie z filozofią może pomóc rozwinąć w kimś bardzo pozytywne cechy, które przydają się także w życiu publicznym (np. cechy takie, jak zdolności analityczne, znajomość historii myśli, antydogmatyzm czy kultura prowadzenia dyskusji).

Dlaczego zatem upierał się, że filozofia nie ma we współczesnych demokracjach liberalnych większej roli do odegrania? Rorty’emu chodziło przede wszystkim o to, że nie istnieje żadna stricte filozoficzna umiejętność, która przysługiwałaby tylko filozofom i która mogłaby mieć istotny wpływ na zmianę naszych społeczeństw. Owszem, filozofowie odznaczają się często zdolnościami analitycznymi lub kulturą dyskusji, ale są to umiejętności, które posiadają również historycy, literaturoznawcy, fizycy czy przedstawiciele innych dyscyplin. Mówiąc inaczej, według Rorty’ego filozofowie nie są w stanie zaproponować społeczeństwom zachodnim jakiegoś głębszego, bardziej fundamentalnego czy choćby w istotny sposób innego podejścia niż to, które oferują pozostali uczestniczy dyskursu publicznego.

Zdaniem Rorty'ego dawniej sytuacja wyglądała trochę inaczej. Jego antyfundamentalizm oraz antyesencjalizm nie pozwalają mu co prawda twierdzić, że filozofowie kiedykolwiek mieli głębszy wgląd w rzeczywistość niż inni ludzie, lecz przyznaje on, że kiedyś ludzie tacy jak Platon oraz Kant pomagali przekształcać społeczną wyobraźnię. Rorty powiada, że filozofia zajmuje ważne miejsce w kulturze jedynie wtedy, gdy „wszystko wydaje się rozpadać - gdy długotrwałe i podzielane szeroko przekonania są zagrożone”. $\mathrm{W}$ takiej sytuacji zjawiają się filozofowie i pomagają nam zinterpretować rzeczywistość na nowo. Amerykański myśliciel wspomina o kilku takich wydarzeniach w historii naszej kultury:

Gdy na przykład zaczęto podejrzliwie spoglądać na modlitwy i kapłaństwo, wtedy Platon i Arystoteles znaleźli sposób, abyśmy nadal trzymali się myśli, że istoty ludzkie, inaczej niż przemijające bez śladu zwierzęta, pozostają w szczególnej relacji z siłami rządzącymi wszechświatem. Gdy Kopernik i Galileusz wymazali obraz świata niosący pociechę Tomaszowi z Akwinu i Dantemu, to

${ }^{3}$ R. Rorty, Democracy and philosophy, „Kritika \& Kontext”, 2006, nr 33 oraz tegoż, Rejoinder to Béla Egyed, „Kritika \& Kontext”, 2007, nr 34. 
Spinoza i Kant uczyli Europę, jak miłość do Boga zastąpić miłością do Prawdy, a posłuszeństwo wobec boskiej woli - czystością moralną. Gdy rewolucje demokratyczne oraz uprzemysłowienie zmusiły nas do przemyślenia na nowo natury więzi społecznych, wówczas Marks i Mill wystąpili z pewnymi użytecznymi koncepcjami ${ }^{4}$.

Czytając powyższy cytat, należy mieć rzecz jasna na względzie, że Rorty próbuje dokonać interpretacji nie tyle poszczególnych koncepcji filozoficznych, ile raczej wpływu, jaki miały one (czasem wbrew intencjom ich autorów) na rozwój naszej kultury. W żadnym razie nie jest to próba eksplikacji filozofii Platona, św. Tomasza czy Kanta. Wracając zaś do wpływu filozofii na sferę publiczną, zdaniem Rorty’ego wkroczyliśmy obecnie w epokę, w której intelektualiści - czyli ludzie potencjalnie mogący wprowadzać filozoficzne idee w szerszy obieg społeczny - szukają rozwiązania podstawowych problemów o charakterze publicznym nie w filozofii, lecz w literaturze ${ }^{5}$. Z tym, że literaturę należy rozumieć $\mathrm{w}$ tym przypadku metaforycznie. Rorty’emu chodzi o wszystkie te rodzaje wypowiedzi, które zamiast na abstrakcyjnych (teoretycznych, metafizycznych) rozważaniach o uniwersalnych właściwościach świata bądź ludzkiej natury, skupiają się na tym, co konkretne, lokalne, niepowtarzalne oraz drobne. Do tak rozumianej „literatury” można zaliczyć na przykład książki etnograficzne lub reportaże dziennikarskie. Ulubionym gatunkiem literackim (w tym wypadku jest to rzeczywiście gatunek literacki) Rorty’ego jest zaś powieściopisarstwo, które w najdoskonalszy sposób realizuje wszystkie powyżej wymienione cechy „literackości”.

$\mathrm{W}$ artykule tym chcę pokazać, że nawet zgadzając się $\mathrm{z}$ antyesencjalistyczno-antyfundacjonalistycznym stanowiskiem Rorty’ego, nie trzeba godzić się na tezę, że filozofia nie ma współcześnie do odegrania żadnej poważnej roli w sferze publicznej. Oczywiście można by w ogóle odrzucić antyesencjalistyczne i antyfundacjonalistyczne założenia autora Konsekwencji pragmaty$z m u$ i polemizować z nim, przyjmując na przykład perspektywę filozofii Platona. Nie taki jest jednak cel mojego tekstu. Zależy mi bowiem na tym, aby wykazać, że poglądy Rorty’ego na temat filozofii nie są logiczną konsekwen-

${ }^{4}$ R. Rorty, Wielkość, głębia i skończoność, [w:] Filozofia jako polityka kulturalna, tłum. B. Baran, Warszawa 2009, s. 123.

${ }^{5}$ Zob. R. Rorty, Zmierzch prawdy ostatecznej i narodziny kultury literackiej, tłum. A. Szahaj, „Teksty Drugie”, 2003, nr 6.

${ }^{6}$ Zob. R. Rorty, Heidegger, Kundera, Dickens, tłum. M. Kwiek, [w:] Między pragmatyzmem a postmodernizmem. Wokól filozofii Richarda Rorty’ego, red. A. Szahaj, Toruń 1995, s. 79-100. 
cją jego antyesencjalizmu, a realizacja takiego celu wymaga, aby użyć przeciw poglądom amerykańskiego myśliciela jego własnych założeń filozoficznych.

Jak już wspomniałem, Rorty przyznaje, że kiedyś filozofia odgrywała niebagatelną rolę w naszej kulturze. Odnosi się nawet wrażenie, że - z pewnością świadomie - przesadza, pisząc o osiągnięciach filozofii. Przyznając tak olbrzymie zasługi filozofii w przeszłości, jednocześnie zupełnie odbiera jej wpływ na współcześnie zachodzące procesy. Dlaczego? Rorty wspomina, że w XX wieku nie wydarzył się tego rodzaju kryzys, który wymagałby nowych idei filozoficznych. Jak twierdzi, obecnie „wszyscy jesteśmy zdroworozsądkowymi materialistami i utylitarystami ${ }^{7 ”}$, stąd filozofia nie ma wiele do zaoferowania. $\mathrm{W}$ innym miejscu twierdzi, że współczesna polityka w państwach liberalnych opiera się na „banalnych, znanych nam terminach, które nie potrzebują filozoficznej analizy ani nie niosą za sobą filozoficznych założeń”". O wiele więcej pożytku przynosi literatura, dlatego Rorty nazywa obecne czasy „kulturą literacką”. Pamiętajmy przy tym, że literaturę należy rozumieć w tym kontekście bardzo szeroko - jako wszystko to, co polega na opisywaniu konkretnych historii konkretnych ludzi.

Swoją polemikę podzielę na trzy części. Będą one zresztą ściśle ze sobą powiązane, ponieważ wszystkie tematy, które w nich poruszę, dotyczą zagadnienia kultury literackiej. O czym dokładnie mają traktować wspomniane części? W pierwszej z nich zamierzam polemizować z tezą, że obywatele zachodnich demokracji (a w szczególności intelektualiści) przesunęli się zdecydowanie na stronę kultury literackiej. W drugiej postaram się pokazać, że choć Rorty ma wiele racji, mówiąc o zasługach literatury, to jednak trzeba wziąć pod uwagę fakt, iż sposób, w jaki czytamy dzieła literackie, jest do pewnego stopnia zależny od filozoficznych pojęć, do których jesteśmy przywiązani. W części trzeciej zwrócę uwagę na to, że istnieją we współczesnych demokracjach takie problemy, przy rozwiązywaniu których literatura wydaje się stosunkowo mało pożyteczna.

${ }^{7}$ R. Rorty, Zmierzch prawdy ostatecznej, s. 143.

${ }^{8}$ R. Rorty, Remarks on Deconstruction and Pragmatism, [w:] Deconstruction and Pragmatism, ed. by Ch. Mouffe, London 1996, s. 17. 


\section{Czy kultura filozoficzna odeszła w niepamięć?}

Być może rzeczywiście duża część ludzi, gdy przychodzi do rozstrzygania politycznych dylematów, jest zdroworozsądkowymi materialistami oraz utylitarystami (choć już ta teza budzi wątpliwości), ale nie znaczy to jeszcze, że wszelkie spory ideowe wygasły i wszystko, co nam pozostało, to pragmatyczne próby rozwiązania przyziemnych problemów politycznych, społecznych i ekonomicznych. Co prawda, w porównaniu $\mathrm{z}$ wielkimi zmianami światopoglądowymi, o których wspomina Rorty, walka różnych koncepcji ekonomicznych bądź refleksja nad rolą nauki mogą wydawać się stosunkowo małe. Nikt jednak nie powiedział, że filozofia musi brać udział tylko w wydarzeniach, które mają olbrzymi zasięg i konsekwencje. Poza tym to, czy jakieś zmiany miały ogromny wpływ na naszą kulturę, widać tak naprawdę dopiero z perspektywy czasu - wiele osób żyjących w czasach Platona mogło nie dostrzegać jakiś specjalnych zmian o charakterze kulturowym. Stąd i my dzisiaj nie jesteśmy w stanie stwierdzić z całkowitą pewnością, czy zachodzą obecnie jakieś poważne zmiany w tzw. kulturze zachodniej, czy też nie. Zasada Hegla wyrażona w metaforze o sowie Minerwy nadal wydaje się powiązywaćs.

Kontrowersyjna jest także teza Rorty'ego, że w XX wieku nie dochodziło do wielkich kryzysów ideowych. Być może, gdyby Rorty zamiast o „kryzysach ideowych” mówił o „konfliktach ideowych” łatwiej byłoby mu je zauważyć. Oczywiście od razu nasuwa się pytanie, jak Rorty może nie uwzględniać wojen światowych i sukcesu leninizmu-stalinizmu. Odpowiedziałby on zapewne, że choć mieliśmy do czynienia z tragicznymi wydarzeniami, to jednak nie spowodowały one tego, że zaczęliśmy poszukiwać nowych idei. Raczej dalej trzymaliśmy się pomysłów wypracowanych już dużo wcześniej (idea demokratycznego państwa, idea praw człowieka, idea swobód obywatelskich, itd.) $\mathrm{z}$ tym, że zaczęliśmy to robić $\mathrm{z}$ większym zdecydowaniem i konsekwencją. Powojenne zmiany polegały raczej na tym, że tworzono nowe instytucje oraz prawa, a nie że poszukiwano nowych filozoficznych pojęć czy koncepcji. Taką odpowiedź można by uznać za w pewnej mierze słuszną, jednakże gubi ona parę szczegółów. Na przykład w naszej części Europy ludzie mogli być świadkami, jak pewne idee, mające swój rodowód w pismach filozoficznych, potrafiły rządzić myśleniem wielu osób, zarówno przed II wojną światową, jaki i po niej. Takim pojęciem-metaforą była na przykład „Historia” - masywna, nie cofająca się przed niczym, zmierzająca w jedynym słusznym kierunku,

\footnotetext{
${ }^{9}$ G. W. F. Hegel, Zasady filozofii prawa, tłum. A. Landman, Warszawa 1969, s. 21.
} 
bezwzględna dla jednostek. Ta metafora zawładnęła umysłami sporej liczby ludzi, którzy wiele decyzji (często podłych) zaczęli tłumaczyć „koniecznością Historii”. Wątek ten poruszył między innymi Czesław Miłosz w swojej książce Zniewolony umys $\mathfrak{1}^{10}$. Przed Historią przestrzegał też Karl Popper ${ }^{11}$. Z pewnością rzeczy, które działy się w Związku Radzieckim oraz państwach mu podległych, często wynikały z bardzo przyziemnych ludzkich przywar (niewiedzy, głupoty, strachu, chciwości, żądzy władzy). Nie należy więc pochopnie tłumaczyć czynów, które wynikały z niskich pobudek tym, że ktoś uwierzył w jakąś filozoficzną ideę Historii. Rację ma Rorty, gdy twierdzi, że wiele negatywnych działań ludzkich wynika z lenistwa, chciwości czy hipokryzji poszczególnych ludzi, a nie z faktu, że osoby te przyjęły błędne przekonania filozoficzne ${ }^{12}$. To prawda, że odwoływanie się do wpływu filozofii byłoby z pewnością zbyt łatwym usprawiedliwieniem dla wielu działań, za którymi stały brudne i trywialne intencje (dlatego właśnie niektórzy zarzucali Miłoszowi, że zbytnio uszlachetnia powody działania opisywanych przez siebie postaci). Nie oznacza to jednak, że tego rodzaju filozoficzne metafory jak Historia zupełnie nie oddziaływały na wyobraźnię i czyny wielu ludzi. Miłosz i Popper mieli powody, aby ostrzegać przed Historią. Tłumaczenie każdego występku cechami charakteru jest tak samo mało wiarygodne jak składanie wszystkiego na karb przyjęcia zgubnych idei filozoficznych.

Nasuwa się jeszcze jedna wątpliwość co do tezy Rorty'ego o tym, że kultura filozoficzna została zastąpiona przez kulturę literacką. Amerykański filozof zdaje się czasami zbyt pochopnie oceniać stan całej kultury zachodniej po sobie. Na początku Przygodności, ironii i solidarności stwierdza on, że historycystyczny zwrot, jaki się dokonał w humanistyce, „pomógł nam uwolnić się od teologii i metafizyki - od pokusy szukania ucieczki przed czasem i przypadkowością"13. Zwraca uwagę liczba mnoga ${ }^{14}$ - tak jak gdyby Rorty pisał o wszystkich lub większości intelektualistów zachodnich. W podobnym tonie wypowiada się on w tekście Zmierzch prawdy ostatecznej i narodziny kultury

${ }^{10}$ Cz. Miłosz, Zniewolony umysł, Kraków 2004.

${ }^{11}$ K. Popper, Społeczeństwo otwarte i jego wrogowie, tłum. H. Krahelska, t. 2, Warszawa 1993, s. $272-293$.

${ }^{12}$ R. Rorty, Response to Simon Critchley, [w:] Deconstruction and Pragmatism, s. 45.

${ }^{13}$ R. Rorty, Przygodność, ironia i solidarność, tłum. W. J. Popowski, Warszawa 2009, s. 14.

${ }^{14}$ Liczba mnoga jest obecna nie tylko w tłumaczeniu, ale także $w$ angielskim oryginale: „This historicist turn has helped free us, gradually but steadily, from theology and metaphysics from the temptation to look for an escape from time and chance". R. Rorty, Contingency, Irony, and Solidarity, Cambridge 1989, s. XIII. 
literackiej: „[...] intelektualiści na Zachodzie od czasów Renesansu przeszli przez trzy etapy: mieli nadzieję na znalezienie spełnienia przez Boga, potem przez filozofię, a obecnie przez literaturę"15.

Teza mówiąca o tym, że większość intelektualistów porzuciła metafizykę, wydaje się nazbyt pochopna. Zresztą sam Rorty w Przygodności, ironii i solidarności parędziesiąt stron po tym, jak pisze o historycystycznym zwrocie, który rzekomo uwolnił nas od metafizyki, przyznaje, że każdego, kto wysuwa takie tezy jak on, posądza się o relatywizm, irracjonalizm i niemoralność ${ }^{16}$. Pogląd, że intelektualiści znaleźli się po stronie kultury literackiej, w której panują antyesencjalistyczne założenia, wydaje się zatem trochę przesadzony. Powiedziałbym raczej, że obecnie intelektualiści i w ogóle mieszkańcy Zachodu żyją we wszystkich trzech kulturach wyróżnionych przez Rorty’ego: religijnej, filozoficznej i literackiej. Nawet jeśli ktoś przeszedł na stronę kultury literackiej, to i tak wszędzie będzie spotykał się z przedstawicielami innych kultur. Zdarza się nawet, że ta sama osoba ciągle podróżuje tam i z powrotem między tymi trzema kulturami. Mogłoby się to wydawać nieprawdopodobne i rodzić podejrzenia, że ktoś taki musi nieuchronnie popaść w kulturową schizofrenię, ale należy pamiętać, iż zdolność poruszania się między różnymi światopoglądami jeszcze chyba nigdy nie była tak duża jak współcześnie, ponieważ wiele osób nie przywiązuje się już do swoich poglądów tak jak kiedyśs $^{17}$.

Stwierdzenie, że znajdujemy się obecnie w epoce literackiej jest zatem do przyjęcia tylko pod pewnymi warunkami. Po pierwsze, konflikty ideowe choć może są bardziej rozproszone i nie rozgrywają się na tak wielką skalę jak kiedyś - nadal toczą się wewnątrz naszych społeczeństw. Po drugie, pojęcia, które pojawiają się w tych konfliktach, są bardzo często wzięte z pism filozoficznych, choć sami użytkownicy tych pojęć mogą nie zdawać sobie z tego sprawy (przykład pojęcia „Historii”). Po trzecie, kultura literacka współistnieje $\mathrm{z}$ dwoma pozostałymi kulturami wymienionymi przez Rorty'ego.

Czy idea solidarności potrzebuje filozoficznego wsparcia?

\footnotetext{
${ }^{15}$ R. Rorty, Zmierzch prawdy ostatecznej i narodziny kultury literackiej, tłum. A. Szahaj, „Teksty Drugie", 2003, nr 6, s. 115.

${ }^{16}$ R. Rorty, Przygodność, ironia i solidarność, s. 81.

${ }^{17} \mathrm{Na}$ temat zgubnych skutków tego procesu zob. np. R. Sennett, Korozja charakteru. Osobiste konsekwencje pracy w nowym kapitalizmie, tłum. J. Dzierzgowski, Ł. Mikołajewski, Warszawa 2006.
} 
Wątpliwości budzi także inna teza stawiana przez Rorty’ego - zresztą jest ona ściśle powiązana z poglądem mówiącym, że nastała kultura literacka. Chodzi o twierdzenie, że to powieści (czy ogólniej - literatura i wszystko to, co skupia się na konkrecie: filmy, reportaże, badanie antropologiczne) $\mathrm{w}$ największym stopniu przyczyniają się do pożądanych z liberalnego punktu widzenia zmian. W pewnym sensie amerykański filozof ma rację. Do niektórych celów literatura rzeczywiście nadaje się szczególnie dobrze. Trzeba pamiętać, że dla Rorty’ego największą wartość stanowi solidarność. Wielokrotnie podkreślał on, że tym, czego potrzebujemy, jest poszerzanie zakresu obowiązywania zaimka "my” na jak największą liczbę osób. Z perspektywy liberalnej na tym polegał w dużej mierze moralny postęp zachodniej kultury. Zaczęliśmy w obręb „my” włączać coraz więcej grup społecznych: kobiety, ludzi innych ras, innych wyznań, o innej preferencji seksualnej itd.

Jest niewątpliwie wiele słuszności w twierdzeniu, że literatura oraz film najlepiej sprawdzają się w zadaniu poszerzania zakresu naszej solidarności na kolejne wykluczone grupy społeczne. Z pewnością łatwiej oburzyć się na patriarchat, kiedy czyta się lub ogląda opowieści o niesłusznie skrzywdzonych kobietach, niż gdy wysłuchuje się abstrakcyjnych rozważań o równości płci (szczególnie wtedy, gdy są one prowadzone za pomocą bardzo wymyślnego, poststrukturalistycznego żargonu). Jednakże jeśli Rorty chciałby być konsekwentnie antyesencjalistyczny, musiałby przyznać, że dostrzeżenie w danym utworze kogoś skrzywdzonego i zasługującego na współczucie wymaga odpowiedniego podejścia interpretacyjnego, to zaś jest uzależnione m.in. od tego, jakich pojęć używamy do interpretowania literatury ${ }^{18}$. „Solidarnościowe" odczytania nie są czymś oczywistym. Weźmy przykład. Cytuję poniżej fragment Burzy Szekspira. Jest to monolog Kalibana, mieszkańca wyspy, na której lądują Prospero z córką, główni bohaterowie dzieła angielskiego dramatopisarza. Kaliban bardzo szybko staje się sługą przybyszów. W pewnym momencie w taki sposób reaguje on na rozkazy Prospera:

Całą tę wyspę mam w spadku po matce -

Tyś mi ją zabrał. Kiedyśs tu się zjawił,

Wpierw byłeś dobry, głaskałeś, dawałeś

Wody i jagód; i nawet uczyłeś,

Jak się nazywa duże światło w dzień

I małe w nocy. Lubiłem cię wtedy,

${ }^{18} \mathrm{Na}$ temat antyesencjalistycznego podejścia do zagadnienia interpretacji zob. S. Fish, Interpretacja, retoryka, polityka, tłum. A. Szahaj [i. in.], Kraków 2007. 
Pokazywałem ci wszystko na wyspie -

Słodkie i słone źródła, nieużytki

I żyzne ziemie. Co ja narobiłem!

Niech cię opadną chrząszcze, nietoperze,

Ropuchy - wszystkie plagi mojej matki!

Ja, który byłem swoim własnym królem,

Dziś jestem waszym jedynym poddanym

I moim domem zamiast całej wyspy,

Jest brudna skalna grota ${ }^{19}$.

Duża część współczesnych czytelników (szczególnie tych zajmujących się postkolonializmem i badaniami kulturowymi) zinterpretuje przytoczony fragment jako dosyć przejmującą skargę mieszkańca, na którego ziemi pojawił się „cywilizowany człowiek”, przynosząc wraz ze swoimi błyskotkami oraz wiedzą także zniewolenie. Co więcej, czytelnicy ci mogą użyć monologu Kalibana jako dowodu na to, że mieszkańcy zachodu bardzo łatwo przechodzą do porządku dziennego nad krzywdą ludzi postrzeganych przez nich jako mniej cywilizowani. Jednakże antyesencjalista Rorty musi przyznać, że nie jest to takie odczytanie tego fragmentu, które każdej osobie od razu musi rzucać się w oczy. Przejście od przytoczonego fragmentu Burzy do poglądu, że w naszym świecie pewne rzeczy były lub nawet nadal są niedobrze urządzone nie jest takie oczywiste. Żyjemy w epoce, w której studia postkolonialne, feminizm, teorie queer oraz tzw. studia kulturowe skłoniły dużą liczbę osób do tego, aby słyszeć w utworach literackich głos skrzywdzonych mniejszości ${ }^{20}$. Stąd też wielu czytelników może odruchowo odnieść monolog Kalibana do stanu społeczeństw zachodnich i grzechów, których się one dopuściły. Dzieje się tak nie dlatego, że jest to oczywisty odruch, lecz dlatego, że ludzie tacy, jak Rorty, Stephan Greenblatt ${ }^{21}$, Judith Butler czy Edward Said „namówili” wiele osób do tego, aby patrzeć na teksty literackie w ten sposób. Już sam pomysł,

\footnotetext{
${ }^{19}$ W. Shakespeare, Burza, tłum. S. Barańczak, Kraków 1999, akt I, scena 2, s. 31.

${ }^{20}$ Pomijam tutaj problem tego, czy szerokie rozpowszechnienie się feministycznych oraz postkolonialnych sposobów lektury ma zawsze pozytywne skutki. Harold Bloom, amerykański literaturoznawca, twierdził, że doprowadziło to do sytuacji, w której zamiast oceniać wartości artystyczne danego utworu, patrzy się na stopień jego postępowości. O obecnej dominacji nurtów takich jak feminizm, postkolonializm czy badania kulturowe w literaturoznawstwie piszą np. A. Burzyńska i M. P. Markowski w swoim podręczniku Teorie literatury XX wieku. Podręcznik, Kraków 2007, s. 40-41.

${ }^{21}$ Od niego zresztą zapożyczyłem przykład z Burzy. Zob. S. Greenblatt, Kultura, tłum. A. Rajca-Salata, [w:] tegoż, Poetyka kulturowa. Pisma wybrane, Kraków 2006, s. 156.
} 
żeby szukać powiązań między tym, co jest opisane w tekście oraz tym, jak wygląda otaczająca nas rzeczywistość, jest czymś, co nie zawsze było obowiązującą doktryną na wydziałach uniwersyteckich. Na przykład w czasach panowania strukturalizmu i Nowej Krytyki dzieło literackie było na różne sposoby odcinane od przyziemnych, codziennych spraw. Nie twierdzę, że nikt nigdy przed czasami feminizmu oraz postkolonializmu nie dostrzegał w literaturze wątków wskazujących na krzywdę wszelakich grup. Nie chcę też przekonywać do absurdalnej tezy, że trzeba się koniecznie utożsamiać z feminizmem lub postkolonializmem, aby upominać się o prawa kobiet bądź osób z innych kręgów kulturowych. Twierdzę jedynie, że taka „solidarnościowa” lektura nie jest naturalnym podejściem do dzieł literackich (nie ma bowiem czegoś takiego jak naturalne podejście - każde jest w jakimś stopniu wyuczone). Sadzę ponadto, że feminizm, teorie queer, postkolonializm i badania kulturowe wyczuliły wiele osób na sprawy wykluczenia i marginalizacji w szczególnie silny sposób (pozostawiam jednocześnie na boku ewentualne skutki uboczne, jakie ma rozpowszechnienie się tych sposobów czytania). Co więcej, i to jest sedno mojego argumentu, wszystkie te nurty sięgały i nadal sięgają po filozoficzne słownictwo. Takie terminy jak choćby gender, hegemonia czy imperializm (w znaczeniu, jakie nadał mu Said) - cokolwiek by o nich nie sądzić - są pojęciami, który niosą za sobą ewidentne założenia filozoficzne. Tak więc to właśnie w dużej mierze dzięki zaproponowaniu odpowiedniej siatki pojęciowej (o filozoficznych konotacjach) przedstawiciele wymienionych powyżej nurtów nakłaniają do tego sposobu lektury, który Rorty’emu jest szczególnie bliski (choć nawet on przyznawał, że niektórzy przedstawiciele tych nurtów idą zdecydowanie za daleko w nieustannym demaskowaniu coraz to nowych form wykluczenia ${ }^{22}$ ).

Zauważmy, że i samo pojęcie solidarności, którym posługuje się Rorty, jest jednym z takich filozoficznych pojęć. Oczywiście, to nie Rorty wymyślił słowo "solidarność" i to nie on pierwszy nadał solidarności ważne miejsce w hierarchii wartości. Jednakże w jego filozofii pojęcie to nabiera specyficznego wydźwięku. Gloryfikacja solidarności w pismach Rorty’ego jest ściśle związana $\mathrm{z}$ innymi jego tezami $-\mathrm{z}$ antyesencjalizmem, $\mathrm{z}$ tezą o wyższości konkretu nad abstrakcją oraz wyobraźni nad rygorystycznym rozumowaniem, z poglądem o prymacie literatury itd. Każdy, kto pod wpływem lektury Rorty’ego, zacznie sięgać po pojęcie solidarności, nie będzie używał tylko niewinnego, zupełnie

${ }^{22}$ Zob. R. Rorty, Spetnianie obietnicy naszego kraju. Myśl lewicowa w dwudziestowiecznej Ameryce, tłum. A. Karalus, A. Szahaj, Toruń 2010. 
niefilozoficznego słówka. Przeciwnie, będzie posługiwał się terminem, który jest ściśle związany z określonymi kontekstami filozoficznymi (w tym wypadku będą to przede wszystkim kontekst liberalny i antyesencjalistyczny).

Ktoś mógłby jednak powiedzieć, że nawet wtedy, gdy zgadzamy się z poglądami amerykańskiego myśliciela, nie musimy przejmować od niego żadnych pojęć. Czy nie można z pism Rorty’ego wynieść po prostu przekonania, że dobrze jest czytać literaturę z nastawieniem empatycznym, a jednocześnie darować sobie odwołania do pojęć, których on sam używa? Literatura z pewnością posiada często bardzo mocny emocjonalny wpływ na ludzi. Potrafi nas zmieniać - niekoniecznie w jakiś spektakularny sposób (Jestem teraz innym człowiekiem!), ale bardziej subtelnie, często niedostrzegalnie (np. po przeczytaniu jakiejś książki z trudem będą przechodziły nam przez gardło niektóre stwierdzenia). Na takim emocjonalnym poziomie terminy filozoficzne rzeczywiście nie wydają się szczególnie ważne. Jednakże potrzebujemy pewnych (niekoniecznie od razu filozoficznych) pojęć, które pomogą nam opisać nasze własne stanowisko - nie tylko przed innymi ludźmi, lecz także przed sobą samym. Kiedy ktoś nas pyta „Dlaczego przeciwstawiasz się dyskryminacji homoseksualistów”, to raczej nie odpowiadamy „Dlatego, że przeczytałem wzruszającą książkę o gejach” (chodź taki może być właśnie powód). Zazwyczaj mówimy w takich sytuacjach coś w rodzaju: „Dlatego, że wierzę w ideę solidarności”, „Dlatego, że wierzę, iż ludzie powinni być sobie równi”, „Dlatego, że dyskryminacja jest niesprawiedliwa”. Tak już jest skonstruowana nasza kultura, że potrzebujemy pojęć takich jak solidarność, równość czy sprawiedliwość, aby móc jakoś opisać i uzasadnić własne postępowanie. Tego typu pojęcia, jak zauważa Charles Taylor, pomagają nam budować własną tożsamośćc ${ }^{23}$.

Ktoś mógłby powiedzieć, że „solidarność”, „równość” oraz „sprawiedliwość” są pojęciami potocznymi i nie trzeba czytać filozofów, aby się do nich odwoływać. Problem polega jednakże na tym, że w swoich „potocznych sensach” są one tak ogólne, iż niewiele tak naprawdę tłumaczą. Nie wiem, czy z potocznego rozumienia solidarności wynika, że należy bronić praw czarnoskórych obywateli, ponieważ nie wiem, czy w swoim potocznym sensie słowo „,solidarność" odnosi się do przedstawicieli innej rasy, czy może tylko do białych, zamożnych mężczyzn. Wiem natomiast, że w sensie Rortiańskim bez wątpienia idea solidarności ma zastosowanie także do ludzi czarnoskórych. Nie chodzi

${ }^{23}$ Zob. Ch. Taylor, Narodziny tożsamości, Źródła podmiotowości. Narodziny tożsamości nowoczesnej, cz. I: Tożsamość i dobro, tłum. A. Lipszyc, Warszawa 2001. 
mi przy tym o to, że tylko odwołanie do kontekstu filozoficznego może nadać wieloznacznym słowom jakiś określony sens. Byłby to wyraz niczym nie uzasadnionej megalomanii filozoficznej. Równie dobrze można się odwołać do kontekstu religijnego lub prawnego. Pragnę jedynie zauważyć, iż zwodnicze jest mówienie o tym, że pewne słowa są po prostu pojęciami potocznymi i nie trzeba ich wcale odnosić do bardziej specjalistycznych kontekstów, aby je zrozumieć. Co bowiem mamy na myśli, gdy mówimy o tym, że pewne pojęcia są "potoczne”? Po prostu tyle, że w danym języku występują takie słowa i ludzie używający tego języka potrafią je jakoś zdefiniować, nawet jeśli nigdy nie czytali żadnego filozofa, nie są zbyt religijni, a i prawa zbytnio nie znają. W takim wypadku znaczenie tych pojęć jest jednak albo tak szerokie, że w żaden sposób nie może ono wytłumaczyć naszego postępowania, albo zza ich „potoczności” wychylają się określone znaczenia filozoficzne, religijne bądź prawne, z których ich użytkownicy nie zdają sobie sprawy. Na przykład współcześnie wiele osób odwołuje się bardzo chętnie do pojęcia wolności. Jednakże pojęcie to w swoim potocznym użyciu ma bardzo wiele znaczeń. Znowu, nie wiem, czy z potocznego rozumienia wolności wynika, że państwo nie powinno się wtrącać w sprawy wolnego rynku. Wiem za to, że pojęcie wolności lansowane przez Friedmana łączy się z takim przekonaniem, natomiast pojęcie wolności używane przez Rorty'ego z tego typu skrajnie wolnorynkowym poglądem nie ma wiele wspólnego. Inny przykład. Nie jest jasne, czy z potocznego pojęcia wolności wynika, że powinniśmy w jakiś sposób dbać o nadanie jedności naszej wspólnocie kulturowej. Wiadomo natomiast, że w filozofii Charlesa Taylora idee wolności i spójności kulturowej ściśle się ze sobą łączą. Według autora Narodzin tożsamości wolność polega na realizowaniu wyższych celów. Cele takie wyznaczyć mogą zaś tylko wartości obecne w danej wspólnocie. Dlatego tak ważne jest, aby wspólnota była na płaszczyźnie ideowej uporządkowana i zapewniała nam w miarę przejrzystą hierarchię wartości. Z kolei w filozofii Rorty’ego nie ma większego związku między ideą wolności oraz ideą spójności kulturowej, a jeśli już jakiś związek jest, to taki, że uspójnianie na siłę naszej kultury, może tylko zaszkodzić wolności poszczególnych osób (co nie znaczy, że według Rorty’ego kultura może być totalnym chaosem - po prostu nie kładzie on takiego nacisku na jej spójność jak Taylor).

\section{Czy literatura może pomóc nam uporać się z nauką?}

Jeszcze jedna wątpliwość nasuwa się w związku ze stawianiem przez Rorty’ego literatury na piedestale. Amerykański filozof, gdy mówi o wyzwaniach, 
jakie stały lub nadal stoją przed społeczeństwami zachodnimi, bardzo często odwołuje się do zagadnienia solidarności. Istnieją jednakże takie sprawy, które trudno rozpatrywać przez pryzmat tej idei. Gdy na przykład zaczniemy zastanawiać się nad miejscem nauk ścisłych w demokracjach liberalnych, to pojęcie solidarności okaże się $\mathrm{w}$ tym akurat kontekście mało przydatne. Odwołanie do niego nie pomoże zbytnio w rozstrzygnięciu, która ze stron sporu o rolę nauk we współczesnych społeczeństwach zachodnich ma rację. Oczywiście wiele zależy od tego, czego ten spór będzie dokładnie dotyczył. Poniżej, odwołując się do Polityki natury Bruno Latoura, przedstawię jeden $\mathrm{z}$ wielu problemów związanych $\mathrm{z}$ nauką. Problem ten zdaje się coraz bardziej dotykać współczesne demokracje zachodnie i, jak się wydaje, ani idea solidarności, ani literatura nie bardzo są w stanie pomóc w jego rozwiązaniu.

Już na pierwszej stronie pierwszego rozdziału Latour formułuje jedną z głównych tez Polityki natury: „W gruncie rzeczy natura stanowi poważną przeszkodę, która zawsze powstrzymuje rozwój debaty publicznej”24. Według francuskiego filozofa mniej więcej od XVII wieku doszło do poważnej zmiany w europejskiej debacie publicznej. Symbolicznego początku tej zmiany dopatruje się Latour w Anglii. Doszło tam do polemiki między Robertem Boyleem, jednym $z$ wynalazców pompy próżniowej, oraz Thomasem Hobbesem. W wyniku tej dyskusji narodziło się coś, co Latour nazywa „nowoczesną Konstytucją". Oczywiście nie chodzi tu o jakikolwiek spisany dokument, nowoczesna Konstytucja jest tylko metaforą, która ma zobrazować pewną zmianę kulturową, jaka dokonała się w XVII wieku. Zmiana ta polegała przede wszystkim na tym, że w dyskursie publicznym zaczęto coraz radykalniej oddzielać od siebie to, co społeczne i to, co naturalne ${ }^{25}$. Konsekwencją tego było postępujące rozchodzenie się - używając współczesnego nazewnictwa dla tych dyscyplin - nauk przyrodniczych oraz nauk humanistycznych. Doprowadziło to do sytuacji, w której wielu ludzi uważa, że obydwie te dziedziny mają odmienne przedmioty zainteresowań, które niewiele łączy. Humaniści zajmują się polityką, społeczeństwem, kulturą i wartościami. Przyrodnicy badają zaś naturę oraz fakty. Humaniści zajmują się tym, co płynne, wytworzone, podatne na zmianę, dyskusyjne, partykularne oraz podlegające nego-

\footnotetext{
${ }^{24}$ B. Latour, Polityka natury, tłum. A. Czarnecka, Warszawa 2007, s. 27.

${ }^{25}$ Zob. B. Latour, Nigdy nie byliśmy nowocześni. Studium z antropologii symetrycznej, tłum. M. Gdula, Warszawa 2011, s. 25-72; K. Abriszewski, Poznanie, zbiorowość, polityka. Analiza teorii aktora-sieci Bruno Latoura, Kraków 2008, s. 289-303.
} 
cjacjom. Z kolei do przyrodników należy badanie niezmiennych, twardych, uniwersalnych praw przyrody.

Według Latoura powyższe założenie prowadzi do tego, że natura, nauki (przyrodnicze) oraz naukowcy (przyrodnicy) mają szczególny status w naszych społeczeństwach. Możemy negocjować, jak dokładnie ma wyglądać system polityczny, w którym żyjemy. Możemy krytykować pewne trendy obowiązujące w sztuce. Możemy dyskutować o tym, jakie normy moralne winny obowiązywać w naszych społeczeństwach. Jednakże jeśli chodzi o fakty, które odkrywają nauki przyrodnicze, to nie da się ani z nimi negocjować czy dyskutować, ani ich krytykować. Jak bowiem negocjować z twardymi faktami? Jak dyskutować z zewnętrzną wobec społeczeństwa, niezmienną, uniwersalną naturą? Jaki jest sens krytykować coś, co i tak jest niezależne od nas? Nie tylko nie można krytykować natury, ale i działalności rzetelnych naukowców, którzy w pocie czoła prześlizgują się na „tamtą stronę”, aby przynieść nam w podarku fakty. Pisze Latour: „Chodzi wyłącznie o ucinanie dyskusji przez odwoływanie się do niej [natury - T. M.] jako raz na zawsze ustanowionej jedności - poza procedurą, poza dyskusją, poza kolektywem, ucinanie dyskusji z zewnątrz, które udaremnia w imię natury pracę stopniowej kompozycji wspólnego świata"26.

Latour zwraca uwagę na zastanawiający paradoks. Natura jest z jednej strony na zewnątrz społeczeństwa, ponieważ jej kształt jest zupełnie niezależny od tego, jakie jest społeczeństwo, a z drugiej strony, jak żaden inny byt, zmienia ono nasze wspólnoty nie do poznania. Tajemnice wydarte naturze przez naukowców doprowadziły na wielu poziomach do rewolucji w naszej kulturze. Scjentyzm stał się jedną z nowych religii, telefony komórkowe i Internet zupełnie zmieniły sposób komunikowania się, a badania klimatu wyznaczyły nowe priorytety (np. wielomilionowe kwoty przeznaczane są na ochronę środowiska w wyniku odkryć związanych z ocieplaniem się klimatu). I tak dalej, i tak dalej. Problem, jaki stawia przed nami Latour, jest następujący: Czy możemy sobie pozwolić na to, żeby natura i nauka, które tak bardzo zmieniają nasze społeczeństwa, były nadal traktowane jako coś, co jest poza owymi społeczeństwami i w związku z tym nie podpada pod społeczną krytykę i nie może być podane pod publiczną dyskusję?

Ktoś może zawołać: „Jak to? Czyż nauki nie są pod stałą kontrolą państwa a przez to, w pewnym sensie, pod kontrolą obywateli, których interesy demokratyczne rządy reprezentują (przynajmniej w założeniu). Czy nauki nie zale-

${ }^{26}$ B. Latour, Polityka natury, s. 141. 
żą między innymi od dotacji państwowych?” Przede wszystkim, jeśli już ktoś ma wpływ na naukę, to, niestety, coraz częściej są to prywatni inwestorzy. O tym, jakie opłakane skutki może to przynosić, świadczą chociażby opisane m.in. przez Naomi Klein przypadki, w których różne firmy zlecały specjalistom zbadanie swoich produktów, a gdy okazywało się, że rezultaty nie są dla nich korzystne, to firmy te zakazywały podawania do publicznej wiadomości wyników badań ${ }^{27}$. Oczywiście demokratyczne państwo nadal może wpływać na naukę, np. przez naciski polityczne albo podwyższanie lub obcinanie dotacji w niektórych sferach, ale zawsze jest to traktowane jako niepożądane wtrącanie się tego, co społeczno-polityczne (a więc partykularne) do tego, co naturalne (a więc uniwersalne). Czy jednak powyższy przykład z prywatnymi zleceniodawcami nie świadczy najlepiej o tym, że pomysły Latoura są szalone - że nauka ma się najlepiej, gdy trzyma się ją jak najdalej od partykularnych interesów? Można by na takie pytanie odpowiedzieć, że to zależy od tego, jak rozumiemy „partykularny interes”. Czy oznacza on interes małej grupy osób, którym zależy na zarabianiu pieniędzy, czy chodzi może raczej o interes większości obywateli danego społeczeństwa (np. o ich zdrowie)? Ważne jest też to, w jaki sposób dochodzi do przeforsowania tego interesu za zamkniętymi drzwiami czy w wyniku publicznej dyskusji. Kiedy Latour mówi o włączeniu natury oraz nauk ścisłych do społeczeństwa i do polityki, to nie chodzi mu oczywiście o to, że naukowcy mają chować do szuflady wyniki badań, gdy te okażą się dla kogoś niekorzystne albo że jakakolwiek wąska grupa polityków ma arbitralnie, bez konsultacji społecznych, decydować o nauce. Idzie mu jedynie o to, że nauki i przedmioty ich badań powinny stać się publicznie „krytykowalne”, „dyskutowalne” oraz „negocjowalne”. To się do pewnego stopnia dzieje już teraz, ale twarde trzymanie się opozycji takich jak „natura - społeczeństwo” albo „fakty - wartości” prowadzi według francuskiego socjologa do niepotrzebnych komplikacji. Jak pisze Latour:

Wartości zawsze zjawiają się za późno i za każdym razem stają, by tak rzec, w obliczu faktów dokonanych. Kiedy w imię tego, co powinno być, wartości odrzucają to, co jest, w odpowiedzi słyszą, że opór ustanowionych faktów nie pozwala nic zmienić [...] Wyznaczenie drugiej domeny jest niemożliwe, dopóki nie ustabilizuje się pierwsza - domena faktów, dowodów, bezdyskusyjnych danych Nauki. W następstwie - ale tylko w następstwie - wartości mogą opowiadać o swych priorytetach czy pragnieniach. Skoro klonowanie owiec i myszy

${ }^{27}$ N. Klein, No logo, tłum. H. Pustuła, Izabelin 2004, s. 105-123. 
stało się przyrodniczym faktem, można stawiać teraz „poważne pytania etyczne", czy powinno się, czy też nie klonować ssaki, w tym ludzi ${ }^{28}$.

Latour zwraca uwagę na to, że opozycja „bezdyskusyjna natura - negocjowalne społeczeństwo" sprawia, iż wartości stają się czymś wtórnym i słabszym wobec faktów. Najpierw odkrywamy i produkujemy, a dopiero potem zastanawiamy się, co z tym zrobić. Dualizm ten ma także inne konsekwencje. Przyrodnicy zdobywają niesłychany autorytet w społeczeństwie (bo to przecież oni znają się na tym, co uniwersalne oraz niepodważalne) i bardzo często wykorzystują go do propagowania określonego światopoglądu. Co więcej, obywatele społeczeństw demokratycznych coraz częściej nadzieje na rozwiązanie naszych problemów lokują w kolejnych odkryciach naukowych. Być może wiele spośród trapiących nas kłopotów udałoby się rozwiązać poprzez odpowiednie działania polityczne, ale my zamiast je podejmować, wolimy czekać aż naukowcy przyniosą nam złotą pigułkę lub zbawczy wynalazek, który rozwiąże nasze problemy. Równie dobrze mogą nam jednak „dostarczyć" katastrofę.

To, na ile pomysły Latoura są przemyślane oraz czy ich wprowadzenie jest pożądane, podlega oczywiście dyskusji ${ }^{29}$. Ma on jednak wiele racji, gdy twierdzi, że prawdziwa zmiana roli nauk przyrodniczych w zachodnich społeczeństwach dokona się tylko wtedy, gdy przedefiniujemy pojęcia takie, jak: natura, kultura, społeczeństwo, fakt, wartość - lub gdy w ogóle wymienimy je na inne terminy. Obecnie rozpowszechnione rozumienie tych pojęć skazuje nas bowiem na postrzeganie natury oraz zajmujących się nimi nauk jako w dużym stopniu niezależnych od społeczeństwa i procedur demokratycznych. Krzysztof Abriszewski w kontekście Latoura zwraca też uwagę na to, że nieustanne mnożenie hybryd (bytów, które nie są ani tylko naturalne, ani tylko społeczne) może doprowadzić do naruszenia naszego „uniwersum symbolicznego”. Interpretuję to tak, że jeśli aparat konceptualny, którym się posługujemy, nie będzie potrafił opisać wciąż powiększającej się puli bytów wymykających się łatwemu zaszufladkowaniu jako społeczne bądź naturalne, może to wpędzić naszą kulturę w pewne tarapaty ${ }^{30}$. Stałoby się tak $\mathrm{z}$ tego powodu, że z jednej

\footnotetext{
${ }^{28}$ B. Latour, Polityka natury, s. 147.

${ }^{29} \mathrm{O}$ rozwiązaniach, które proponuje Latour, można przeczytać we wspomnianej Polityce natury, a także w przywoływanej już książce Krzysztofa Abriszewskiego, Poznanie, zbiorowość, polityka, s. 317-349.

${ }^{30} \mathrm{~K}$. Abriszewski, Wszystko otwarte na nowo. Teoria Aktora-Sieci i filozofia kultury, Toruń 2010, s. 117-118. Abriszewski sporą część swojej książki poświęca rozważaniom na temat tego,
} 
strony wciąż mnożyłyby się wokół nas hybrydy, a z drugiej nie potrafilibyśmy ich włączyć do uniwersum symbolicznego, co doprowadziłoby do naruszenia względnej spójności naszych społeczeństw. Choć idea pełnego uspójnienia kultury, pojawiająca się u niektórych filozofów, jest raczej utopią, to jednak pewien stopień spójności wydaje się potrzebny do poprawnego funkcjonowania społeczeństw. Stąd naruszenie tego niezbędnego minimum koherentności mogłoby być niebezpieczne dla zachodnich demokracji.

Podsumowując, pochopne wydaje się twierdzenie Rorty'ego mówiące o tym, że filozofia straciła we współczesnych społeczeństwach zachodnich istotną rolę w domenie publicznej. Jak starałem się dowieść, stanowisko amerykańskiego filozofa ma trzy słabe strony. Po pierwsze, opiera się na mocno kontrowersyjnej tezie, według której znajdujemy się we wnętrzu kultury literackiej. Po drugie, Rorty nie docenia tego, że pewne rodzaje zachowań, które sam pochwala (np. czytanie literatury w sposób „solidarnościowy”), opierają się na filozoficznych pojęciach (albo na takich, które mają filozoficzne konotacje). Po trzecie, autor Konsekwencji pragmatyzmu zdaje się nie dostrzegać pewnych wyzwań, przed którymi stoją liberalne demokracje (typu: jak poradzić sobie z rozwojem nauk), sądząc, że język, jakim obecnie dysponujemy, nie potrzebuje już dalszego wsparcia ze strony filozofów. Teza Rorty’ego o nieistotności filozofii w sferze publicznej napotyka zatem wiele trudności. Co najwyżej można by powiedzieć, że nie ma żadnych jasnych czy dających się z góry przewidzieć relacji między filozofią oraz kondycją współczesnych demokracji liberalnych. Albert Einstein twierdził, że wpływ na jego sposób myślenia, a więc pośrednio także na jego odkrycia miała lektura tekstów filozoficznych, m.in. pism Davida Hume’a. Trudno byłoby jednak wskazać dokładnie, jaki wpływ wywarły filozoficzne teksty na działalność wybitnego fizyka. Nie możemy wziąć prac Einsteina i powiedzieć: „O, w tym równaniu widać wyraźne piętno lektury Hume’a” albo „Einstein nigdy nie napisałby tego zdania, gdyby wcześniej nie czytał Hume’a". Wpływ filozofii na nas jest z reguły trudny do zmierzenia i precyzyjnego wypunktowania. Nawet gdy sądzi się, że konkretne pojęcia (rozum, społeczeństwo, natura, solidarność, hybryda itd.) są naznaczone filozoficznym piętnem, to trzeba przyznać, iż nie

na ile filozofia może pełnić rolę czegoś, co uspójnia uniwersum symboliczne (koncepcję tę przejmuje od Józefa Niżnika). Zob. tamże, s. 107-140. Sądzę, że Rorty dużą część jego przykładów starałby się zepchnąć do sfery prywatnej. To znaczy, dowodziłby on, że filozofia może (nie musi) pomóc niektórym (bo nie wszystkim) uspójnić ich prywatne uniwersum symboliczne. Jednakże z takimi przykładami jak ten $\mathrm{z}$ Latourem byłby spory kłopot, aby sprowadzić je do sfery prywatnej, ponieważ problem wyraźnie rozgrywa się na poziomie publicznym. 
istnieje łatwe do rozpoznania przełożenie między tym, jak pojęcia te funkcjonują w pismach konkretnych filozofów a tym, jak funkcjonują w społeczeństwie. Droga pojęć z pism filozofów do innych obszarów kultury bywa pokrętna. Błędem byłoby jednak wyciągać z tego wniosek, że nie istnieje żaden poważniejszy związek między terminami pojawiającymi się w tekstach filozoficznych a tymi, które krążą po naszej kulturze.

\section{Bibliografia}

Abriszewski K., Poznanie, zbiorowość, polityka. Analiza teorii aktora-sieci Bruno Latoura, Kraków 2008.

Abriszewski K., Wszystko otwarte na nowo. Teoria Aktora-Sieci i filozofia kultury, Toruń 2010.

Burzyńska A., Markowski M. P., Teorie literatury XX wieku. Podręcznik, Kraków 2007. Deconstruction and Pragmatism, ed. by Ch. Mouffe, London 1996.

Fish S., Interpretacja, retoryka, polityka, tłum. A. Szahaj [i in.], Kraków 2007.

Greenblatt S., Kultura, tłum. A. Rajca-Salata, [w:] tegoż, Poetyka kulturowa. Pisma wybrane, Kraków 2006.

Hegel G. W. F., Zasady filozofii prawa, tłum. A. Landman, Warszawa 1969.

Klein N., No logo, tłum. H. Pustuła, Izabelin 2004.

Latour B., Nigdy nie byliśmy nowocześni. Studium z antropologii symetrycznej, tłum. M. Gdula, Warszawa 2011.

Latour B., Polityka natury, tłum. A. Czarnecka, Warszawa 2007.

Miłosz Cz., Zniewolony umyst, Kraków 2004.

Popper K., Społeczeństwo otwarte i jego wrogowie, tłum. H. Krahelska, t. 2, Warszawa 1993.

Rorty R., Contingency, Irony, and Solidarity, Cambridge 1989.

Rorty R., Democracy and philosophy, „Kritika \& Kontext”, 2006, nr 33.

Rorty R., Heidegger, Kundera, Dickens, tłum. M. Kwiek, [w:] Między pragmatyzmem a postmodernizmem. Wokół filozofii Richarda Rorty'ego, red. A. Szahaj, Torun, 1995.

Rorty R., Pierwszeństwo demokracji wobec filozofii, [w:] tegoż, Obiektywność, relatywizm i prawda, tłum. J. Margański, Warszawa 1999.

Rorty R., Przygodność, ironia i solidarność, tłum. W. J. Popowski, Warszawa 2009.

Rorty R., Rejoinder to Béla Egyed, „Kritika \& Kontext”, 2007, nr 34.

Rorty R., Spetnianie obietnicy naszego kraju. Myśl lewicowa w dwudziestowiecznej Ameryce, tłum. A. Karalus, A. Szahaj, Torun 2010.

Rorty R., Wielkość, głębia i skończoność, [w:] Filozofia jako polityka kulturalna, tłum. B. Baran, Warszawa 2009. 
Rorty R., Zmierzch prawdy ostatecznej i narodziny kultury literackiej, tłum. A. Szahaj, „Teksty Drugie”, 2003, nr 6.

Sennett R., Korozja charakteru. Osobiste konsekwencje pracy w nowym kapitalizmie, tłum. J. Dzierzgowski, Ł. Mikołajewski, Warszawa 2006.

Shakespeare W., Burza, tłum. S. Barańczak, Kraków 1999.

Szahaj A., Ironia i miłość. Neopragmatyzm Richarda Rortyego w kontekście sporu o postmodernizm, Wrocław 2002.

Szubka T., Neopragmatyzm, Torun 2012

Taylor Ch., Narodziny tożsamości, Źródła podmiotowości. Narodziny tożsamości nowoczesnej, cz. I: Tożsamość i dobro, tłum. A. Lipszyc, Warszawa 2001.

\section{Abstract \\ Has a Literary Culture Replaced a Philosophical Culture? On Richard Rorty's Views}

The aim of the article is to discuss the public role of philosophy in contemporary western societies. The author of the article doesn't agree with Richard Rorty's thesis that philosophy is useless when it comes to contemporary social-political problems. The American philosopher claims that if one is antiessentialist (as he is) they should not expect any special sort of public utility from philosophers. The author of the article wants to prove that this is possible to accept Rorty's antiessentialism and antifoundationalism and refute his view on the role of philosophy at the same time.

Key words: antiessentialism, antifoundationalism, western societies, philosophical culture, literary culture, Rorty 